\title{
SISTEM INFORMASI LAPORAN PEMERIKSAAN KESEHATAN LANSIA DI RW.05 KELURAHAN PASEBAN BERBASIS WEB
}

\author{
Addin Nullah Arifin ${ }^{1 *}$,Melati Kusuma Budiani ${ }^{2}$, Oda Roswita Aprilia ${ }^{3}$, Nilam Herti \\ Apriyani $^{4}$, M. Arjun Jamaludin ${ }^{5}$, Nita Merlina ${ }^{6}$, Nurajijah ${ }^{7}$ \\ ${ }^{1-7}$ Sistem Informasi, Sekolah Tinggi Manajemen Informatika dan Komputer Nusa Mandiri \\ Indonesia \\ 19adinarifin98@gmail.com, ${ }^{2}$ melatikusumabudiani01@gmail.com, ${ }^{3}$ roswitaoda17@gmail.com, \\ 7nurajijah.nja@nusamandiri.ac.id
}

\begin{abstract}
The reporting of the posyandu for the elderly at $R W 05$, Paseban sub-district is still using the manual method. During the preparation of the report, there were many deficiencies in the completeness of reporting, one of which was writing the names of elderly patients incomplete, there was an inappropriate age of elderly patients, and data on the results of examinations of elderly patients were collected manually, so there is a concern that the data is lost or damaged. The purpose of this study is to create a system to avoid errors in reporting that can be overcome by using web-based reporting of elderly health checks. The method used in system development is the waterfall method. The stages took in making the program are analysis, design, coding, testing, and evaluation. The use of a web-based information system for elderly posyandu reporting can make it easier for cadres to input, search, process, and produce data on visits to elderly patients for the period of months and years. The system can manage elderly patient data, display the results of the recapitulation of reporting the results of the activities of elderly patients monthly and annually, and the system can print reports.
\end{abstract}

Keywords:Information Systems;Elderly examination report; Website

\begin{abstract}
Abstrak
Pelaporan posyandu lansia pada RW 05 kelurahan Paseban masih menggunakan cara manual. Selama pembuatan laporan ditemukan banyak kekurangan dalam kelengkapan pelaporan, salah satu diantaranya seperti penulisan nama pasien lansia tidak lengkap, terdapat umur pasien lansia yang tidak sesuai, serta data riwayat hasil pemeriksaan pasien lansia dikumpulkan secara manual, sehingga dikhawatirkan data tersebut hilang atau rusak. Tujuan penelitian ini adalah membuat sistem untuk menghindari adanya kesalahan dalam pembuatan pelaporan yang dapat diatasi dengan menggunakan pelaporan pemeriksaan kesehatan lansia berbasis web. Metode yang digunakan dalam pengembangan sistem adalah metode waterfall. Tahap yang dilakukan dalam pembuatan program yaitu analisis, desain, pembuatan koding program, testing, dan evaluasi. Penggunaan sistem informasi pelaporan posyandu lansia yang berbasis web dapat mempermudah kader untuk melakukan input, mencari, mengolah, menghasilkan data kunjungan pasien lansia periode bulan dan tahun. Sistem dapat mengelola data pasien lansia, menampilkan hasil rekapitulasi pelaporan hasil kegiatan pasien lansia perbulan dan tahunan, dan sistem dapat melakukan cetak laporan.
\end{abstract}

Kata Kunci: Sistem Informasi; Laporan Pemeriksaan Lansia; Website 


\section{Introduction}

Dampak dari perkembangan dunia Teknologi Informasi dan Komunikasi (TIK) pada saat ini peningkatan akses terhadap internet mulai mengubah gaya hidup manusia dalam berbagai aspek, baik itu didalam bidang ekonomi, politik, hingga kehidupan sosial masyarakat saat ini sudah diwarnai dengan kecanggihan dunia Teknologi Informasi dan Komunikasi(Sundari, 2016).

Saat ini kesehatan menjadi prioritas utama dalam kehidupan manusia. Banyak cara yang dilakukan oleh setiap individu untuk menunjang dan menjaga kesehatan salah satunya dengan mengikuti programprogram yang diselenggarakan oleh pemerintah, diantaranya yaitu kegiatan posyandu(Intarti \& Khoriah, 2018) sebagai wadah pemeliharaan kesehatan yang dilakukan dari, oleh, dan untuk masyarakat yang dibimbing oleh petugas terkait(Ramadhan et al., 2019).Semakin meningkatnya populasi lanjut usia, pemerintah telah merumuskan berbagai kebijakan pelayanan kesehatan lanjut usia ditujukan untuk meningkatkan derajat kesehatan dan mutu kesehatan lanjut usia untuk mencapai masa tua bahagia dan berguna dalam kehidupan keluarga dan masyarakat sesuai dengan keberadaannya (Sari, 2019).Usia lanjut mempunyai dua karakteristik yaitu adanya proses penuaan dan adanya proses penyakit(Keumalahayati \& Alamsyah, 2018).Permenkes RI No. 25 menyatakan bahwa "Posyandu lansia adalah pos pelayanan terpadu untuk masyarakat usia lanjut dikatakan usia lanjut adalah seseorang yang telah mencapai usia 60 (enam puluh) tahun ke atas di suatu wilayah tertentu yang sudah disepakati, digerakkan oleh masyarakat dimana mereka bisa mendapatkan pelayanan Kesehatan"(Rohman \& Aminaa, 2018).Data pelaporan posyandu lansia(Wulansari, 2015) dapat diolah dan digunakan sebagai acuan tindak lanjut penanganan setiap pasien lansia mendatang (Kusumawardani \& Andanawarih, 2018). Pelaporan posyandu lansiapada RW 05 kelurahan Paseban selama ini masih menggunakan cara manual, selama pembuatan laporan ditemukan banyak kekurangan dalam kelengkapan pelaporan, salah satu diantaranya seperti penulisan nama pasien lansia tidak lengkap, terdapat umur pasien lansia yang tidak sesuai, serta data riwayat hasil pemeriksaan pasien lansia dikumpulkan secara manual, sehingga dikhawatirkan data tersebut hilang atau rusak. Penelitian sebelumnya telah dilakukan dengan membuat rancangan sistem pencatatan data pelayanan posyandu berbasis desktop dengan tujuan 
mempermudah pengolahan data pelayanan yang ada di posyandu(Kristania \& Yulianti, 2019). Sistem informasi rekam medis dirancang menggunakan Aliran Sistem Informasi (ASI), Context Diagram (CD), Data Flow Digram (DFD), Entity Relationship Diagram (ERD) serta bentuk cetak laporan yang dihasilkan (Tanjung, 2017). Penggunaan sistem informasi pelaporan posyandu lansia dapat mempermudah kader dan petugas pelaporan untuk melakukan input, mencari, mengolah, menghasilkan data kunjungan pasien lansia (Rohman \& Agnia, 2019). Pelaksanaan pengabdian masyarakat untuk meningkatkan pengetahuan petugas kesehatan dalam mengelola formulir rekam medis yang sesuai dengan standar, dan terdokumentasinya pemeriksaan lansia secara berkesinambungan (Nuraeni et al., 2020).

Berdasarkan permasalahan dan penelitian yang telah dilakukan maka perlu adanya sistem yang dirancang menghindari kemungkinan adanya kesalahan dalam pembuatan pelaporan pemeriksaan kesehatan lansia.Tujuan penelitian ini adalah merancang sistem untuk menggantikan proses pelaporan manual data pemeriksaan kesehatan lansia. Sistem yang dirancang dapat digunakan dengan mudah oleh petugas posyandu dan sangat efisien dalam menginput pencatatan laporan pengecekan kesehatan lansia dengan berbasis web(Syukron \& Hasan, 2015)(R. Hidayat, n.d.). Penggunaan sistem informasi pelaporan posyandu lansia dapat mempermudah kader dan petugas pelaporan untuk melakukan input, mencari, mengolah, menghasilkan data kunjungan pasien lansia periode bulan dan tahun. Sistem dapat mengelola data pasien lansia, menampilkan hasil rekapitulasi pelaporan hasil kegiatan pasien lansia perbulan dan tahunan, dan sistem dapat melakukan cetak laporan.

\section{Material and Method}

Sistem dirancang menggunakan metode waterfall(Nurajijah \& Indriani, 2017) dengan tahapan analisis, desain, pembuatan koding program, testing, dan evaluasi. Pada tahap analisis kebutuhan sistem perlu adanya fitur untuk admin melakukan login, mengelola data lansia dan rekam medis hingga cetak laporan.

Pada bagian selanjutnya untuk desain menggunakan UML (Unified Modelling Language). UML(Unified Modelling Language) adalah adalah sistem notasi yang sudah dibakukan di dunia pengembangan sistem, UML yang terdiri dari serangkaian diagram yang memungkinkan bagi sistem analis untuk membuat cetak biru sistem yang komprehensif kepada klien, programmer dan tiap orang yang terlibat dalam proses pengembangan sistem 
tersebut. Dengan UML akan bisa menceritakan apa yang seharusnya dilakukan oleh sebuah sistem bukan bagaimana yang seharusnya dilakukan oleh sebuah sistem (Waluyo \& Fatich, 2017).

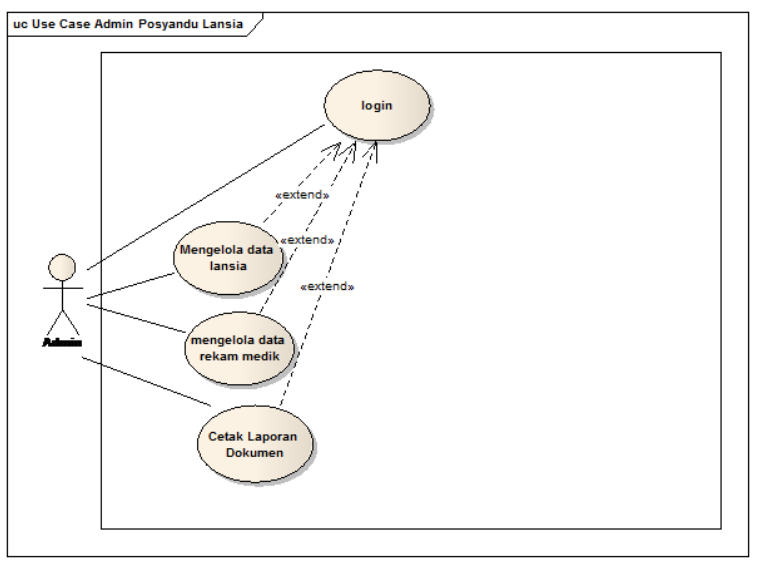

Gambar 1. Usecase Diagram Admin Posyandu Lansia

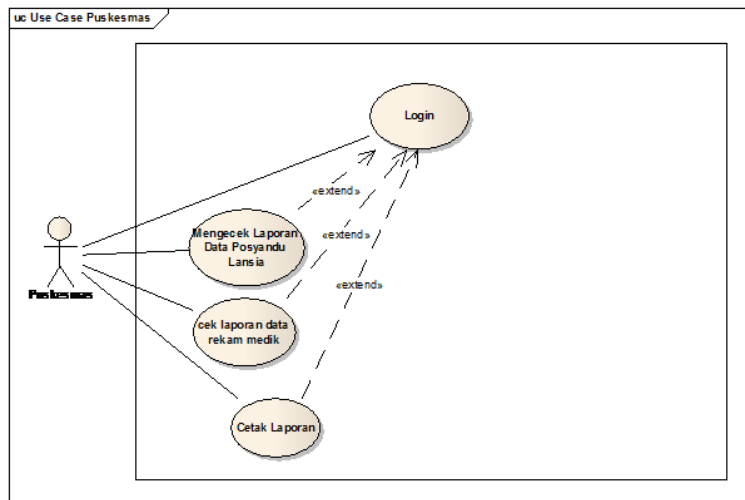

Gambar 2. Usecase Diagram Admin Puskesmas

Tahapan UML meliputi: alur usecase diagram admin posyandu lansia yaitu mengelola data lansia, rekam medik dan cetak laporan dokumen. Alur usecase diagram admin puskesmas yaitu memeriksa laporan data posyandu, data rekam medik dan cetak laporan dokumen. Usecase diagram admin posyandu lansia dapat dilihat pada gambar 1 dan usecase diagram admin puskesmas pada gambar 2 .

Alur activity diagram login posyandu lansia dan alur activity diagram login puskesmas yaitu melakukan login, memasukan username dan password jika benar akan menampilkan tampilan menu utama dan jika salah akan kembali memasukkan username dan password. Activity diagram login posyandu lansia dapat dilihat padagambar 3 danactivitydiagram puskesmas pada gambar 4 .

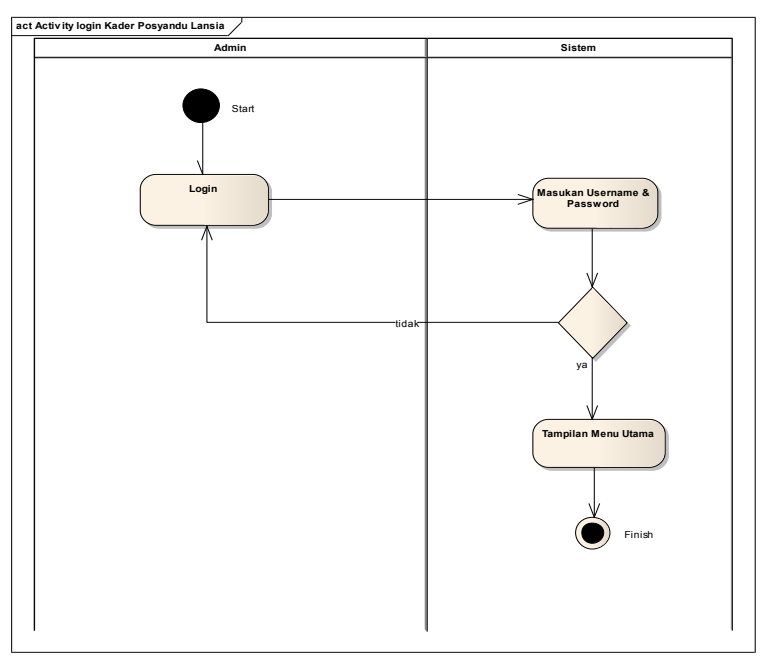

Gambar 3. Activity Diagram Login Posyandu Lansia

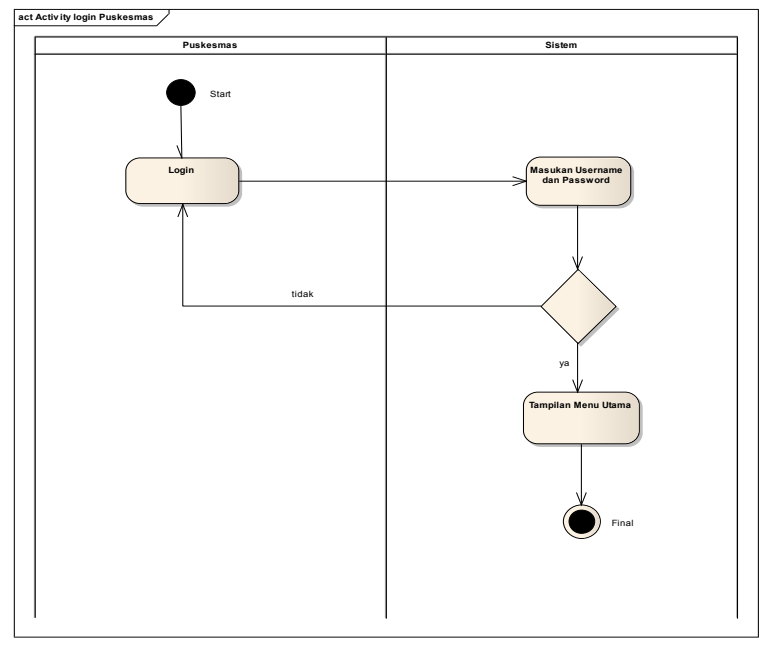

Gambar 4. Activity Diagram Login Puskesmas 
Alur activity diagram mengelola data lansia pada gambar 5 yaitu menginput data lansia dengan cara menambah, mengubah data lansia dan mengubah status lansia yaitu meninggal, menetap atau pindah. Alur activity diagram puskesmas cek laporan data lansia pada gambar 6yaitu memilih halaman data lansia lalu memeriksa data lansia yang sudah diinput melalui admin posyandu lansia.

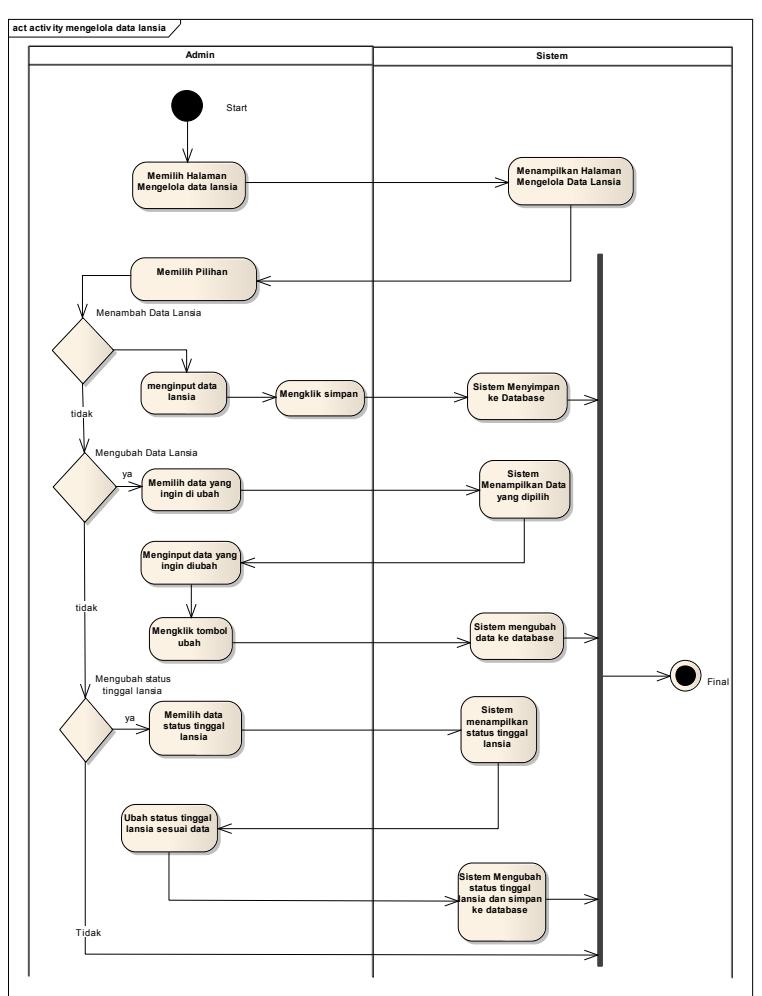

Gambar 5. Activity Diagram Mengelola Data Lansia

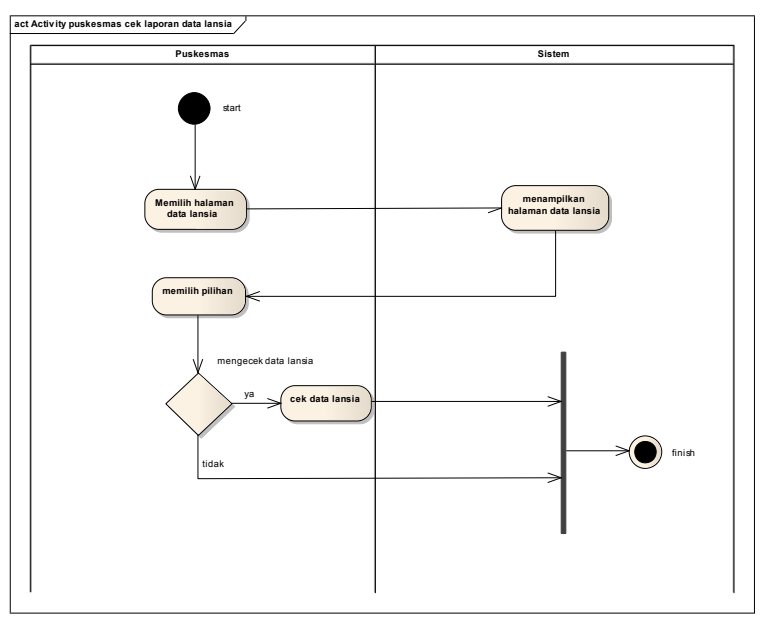

Gambar 6. Activity Diagram Puskesmas Cek Laporan Lansia

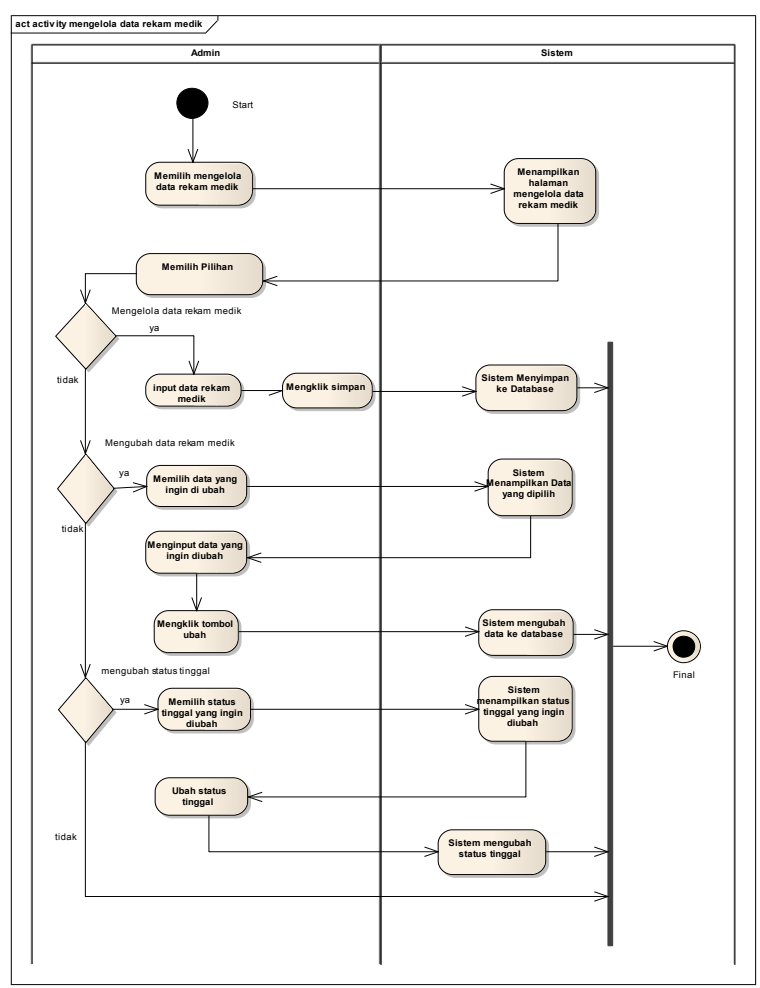

Gambar 7. Activity Diagram Mengelola Data Rekam Medik

Alur activity diagram mengelola data rekam medik pada gambar 7yaitu menginput data rekam medik dengan cara menambah, mengubah data rekam medik dan mengubah status tinggal lansia yaitu meninggal, menetap atau pindah. Alur activity diagram cek laporan data rekam medikpada gambar 
8yaitu memilih halaman data rekam medik lalu memeriksa data rekam medik yang sudah diinput melalui admin posyandu lansia.

Alur activity diagram cetak laporan data lansiapada gambar 9 yaitu mencetak laporan data lansia berdasarkan bulan dan tahun data lansia diperoleh. Alur activity diagram puskesmas cetak laporan data lansiapada gambar 10yaitu mencetak laporan data lansia berdasarkan bulan dan tahun data lansia diperoleh.

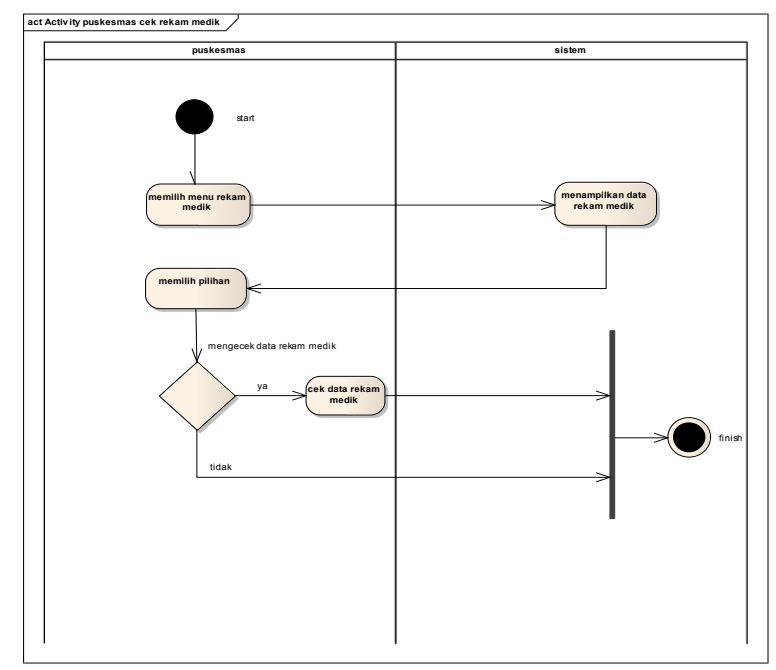

Gambar 8. Activity Diagram Puskesmas Cek Laporan Data Rekam Medik

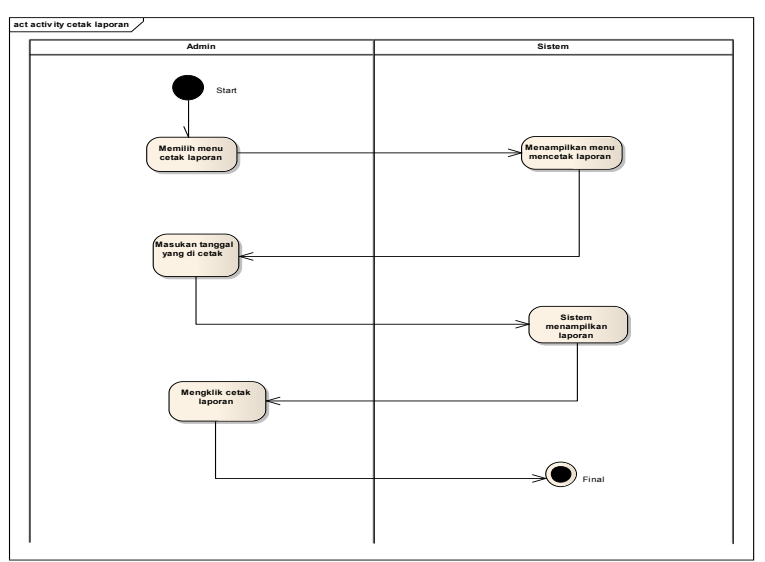

Gambar 9. Activity Diagram Cetak Laporan Data Lansia
Alur sequence diagram posyandu lansia pada gambar 11yaitu pada tahap pertama admin posyandu lansia memasukkan username dan password setelah itu akan muncul tampilan halaman utama website posyandu lansia selanjutnya admin posyandu lansia akan mengelola data lansia, menginput data lansia apabila ingin mengubah akan ada tombol ubah data lansia dan apabila ingin mengubah status tinggal lansia yang sudah pindah, menetap ataupun yang meninggal akan ada tombol mengubah status data lansia.

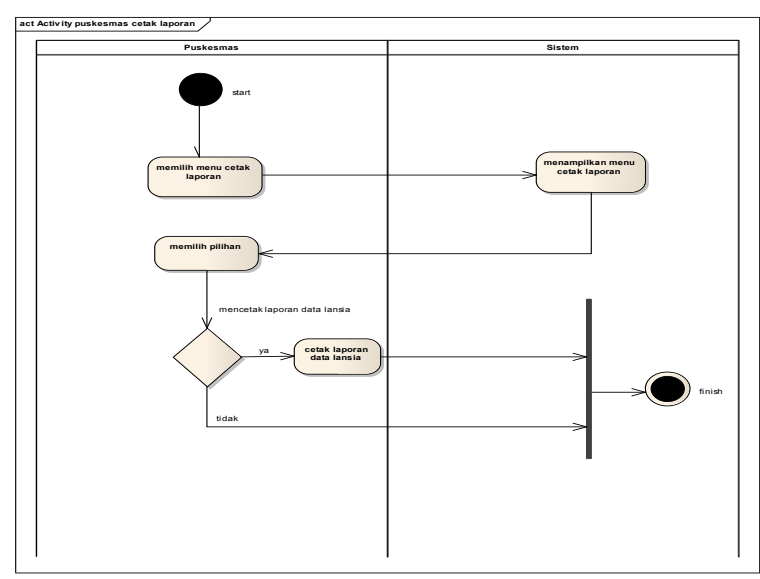

Gambar 10. Activity Diagram Puskesmas Cetak Laporan Data Lansia 


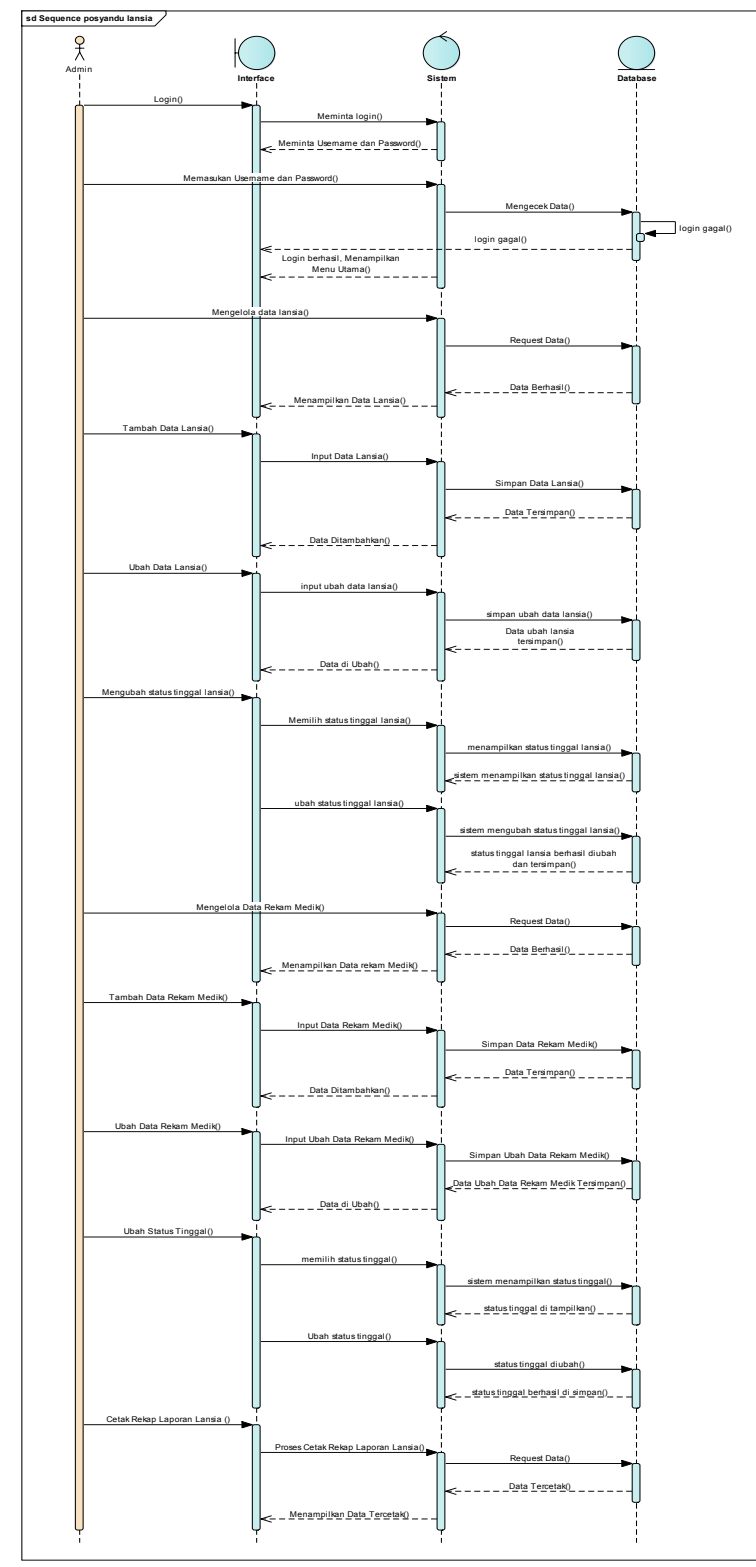

Gambar 11. Sequence Diagram Admin Posyandu Lansia

Pada tahap kedua admin posyandu lansia mengelola data rekam medik dengan cara menginput data rekam medik, mengubah data rekam medik dan mengubah status tinggal lansia. Pada tahap ketiga admin posyandu lansia akan mencetak data laporan lansia seluruhnya apabila data dibutuhkan.

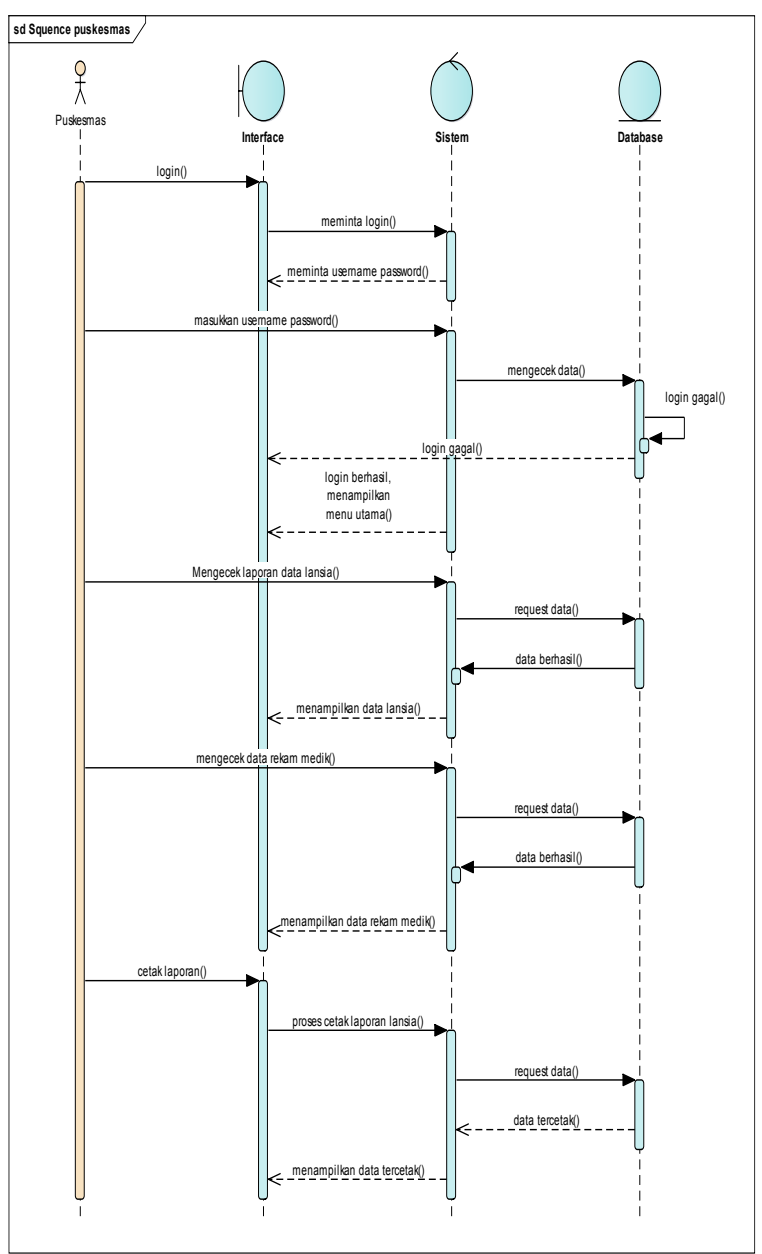

Gambar 12. Sequence Diagram Admin Puskesmas

Alur sequence diagram puskesmas pada gambar 12 yaitu admin puskesmas memasukkan username dan password setelah berhasil akan dialihkan kehalaman utama. Di halaman utama terdapat menu data lansia serta data rekam medik lalu admin puskesmas hanya dapat memeriksa atau menampilkan data lansia dan data rekam medik yang sudah berhasil diinput. Selanjutnya admin puskesmas dapat mencetak laporan data lansia berdasarkan tanggal data yang ingin dicetak.

\section{Results and Discussion}


Kuesioner(Risanty \& Sopiyan, 2017) pada gambar 13 adalah yang dibagikan kepada para kader posyandu untuk dasar pengumpulan data kinerja website posyandu lansia.

\begin{tabular}{|c|l|l|l|l|l|}
\hline \multirow{2}{*}{ No } & \multicolumn{2}{|c|}{ Pernyataan } & \multicolumn{3}{c|}{ Peniaian } \\
\cline { 3 - 5 } 1 & $\begin{array}{l}\text { Sistem Laporan Lansia yang kami } \\
\text { buat sesuai dengan kebutuhan para } \\
\text { kader posyandu }\end{array}$ & & & & \\
\hline 2 & $\begin{array}{l}\text { Materi yang kami sampaikan sangat } \\
\text { bermanfaat untuk para kader } \\
\text { posyandu }\end{array}$ & & & \\
\hline 3 & $\begin{array}{l}\text { Metode cara penyampaian } \\
\text { penggunaan sistem mudah } \\
\text { dimengerti }\end{array}$ & & & \\
\hline 4 & $\begin{array}{l}\text { Sistem Laporan Lansia selalu } \\
\text { update }\end{array}$ & & & \\
\hline 5 & $\begin{array}{l}\text { Sistem Laporan Lansia } \\
\text { mempermudah untuk mencatat } \\
\text { kesehatan lansia }\end{array}$ & & & \\
\hline 6 & $\begin{array}{l}\text { Dengan adanya Sistem Laporan } \\
\text { Lansia, data lansia menjadi lebih } \\
\text { tersusun rapih }\end{array}$ & & & \\
\hline 7 & $\begin{array}{l}\text { Sistem Laporan Lansia } \\
\text { mempersingkat waktu pelaksanaan } \\
\text { posyandu lansia }\end{array}$ & & & \\
\hline 8 & $\begin{array}{l}\text { Laporan pertahun perbulan dapat } \\
\text { dihasilkan dengan mudah dan sesuai } \\
\text { kebutuhan }\end{array}$ & & & \\
\hline 9 & $\begin{array}{l}\text { Sistem Laporan Lansia dapat } \\
\text { menghasilkan data yang lebih } \\
\text { akurat atau fleksibel }\end{array}$ & & & \\
\hline 10 & $\begin{array}{l}\text { Sistem Laporan Lansia dapat } \\
\text { diakses melalui semua komputer } \\
\text { dengan memasukkan username dan } \\
\text { password }\end{array}$ & & & \\
\hline
\end{tabular}

Gambar 13. Kuesioner

Berdasarkan data dari kuesioner pada gambar 13yang sudahdiolah menjadi sebuah grafik pada gambar 14 terdapat angkayangpaling tinggi untuk 2 pernyataan yaitupernyataan pada nomor 4 dengan total 38tentang sistem laporan lansia selalu updatedanpernyataan nomor 7 dengan total 38 tentangsistem laporan lansia mempersingkat waktupelaksanaan posyandu

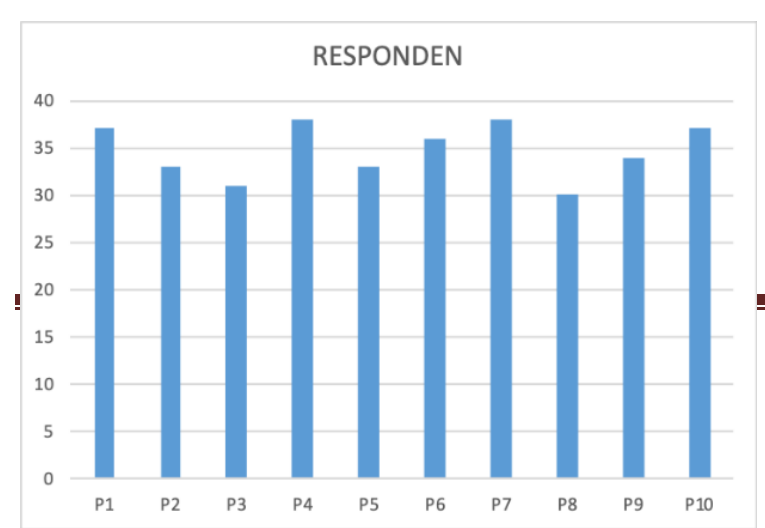

lansia.

Gambar 14. Grafik Kuesiner Posyandu Lansia

Websiteposyandu lansia adalah websiteyang berguna bagi para kader posyandu karena sangat memudahkan pencatatan data lansia dan data rekam medik sehingga meminimalisir kesalahan dalam pencatatan data lansia ataupun rekam medik yang sebelumnya dicatat secara manual.

Pada penelitian ini website dibuat dengan bahasa pemrograman PHP, PHP adalah pemrograman interpreter yaitu proses penerjemahan baris kode sumber menjadikode mesin yang dimengerti komputer secara langsung pada saat baris kode dijalankan. PHP disebut sebagai pemrograman Server Side Programming, hal ini dikarenakan seluruh prosesnya dijalankan pada server tidak dijalankan pada client. PHP merupakan suatu bahasa dengan hak cipta terbuka atau yang juga dikenal dengan istilah Open Source, yaitu pengguna dapat mengembangkan kode fungsi PHP dengan kebutuhannya $(H$. Hidayat et al., 2017)dan tools yang digunakan adalah sublime text 3. Serta MySQL, MySQLmerupakan sistem manajemen database(Yulianita et al., 2015)yang menggunakan tools XAMPP, XAMPP adalah perangkat lunak bebas (free software) yang mendukung banyak sistem operasi, merupakan kompilasi dari beberapa program. (Haqi \& 
Setiawan, 2019).Tampilan login web dapat dilihat pada gambar 15 .

\section{Login Posyandu Lansia \\ ( Login yourself to get access )}

Masukan Username dan Password

- Your Username

- Your Password

\section{Login}

Gambar 15. Form Login Posyandu Lansia

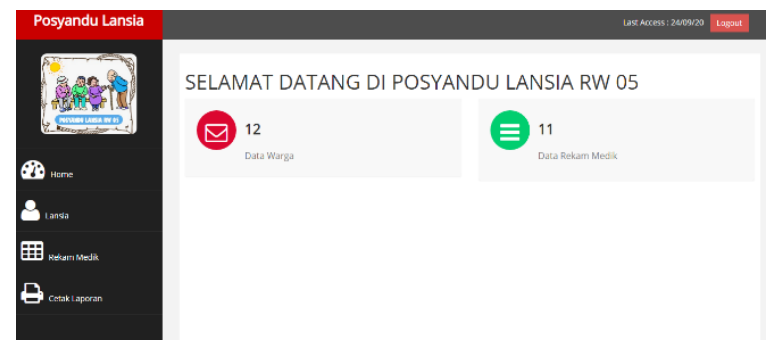

Gambar 16. Tampilan Utama Admin Posyandu Lansia dan Puskesmas

Pada gambar 16 tampilan utama admin posyandu lansia dan admin puskesmas mempunyai kesamaan dan terdapat menu home yang meliputi banyaknya data warga lansia dan data rekam mediknya, menu lansia yang meliputi data lansia yang sudah di input, menu rekam medik meliputi data rekam medik yang sudah di input dan menu cetak laporan untuk mencetak laporan berdasarkan perbulan dan pertahun.

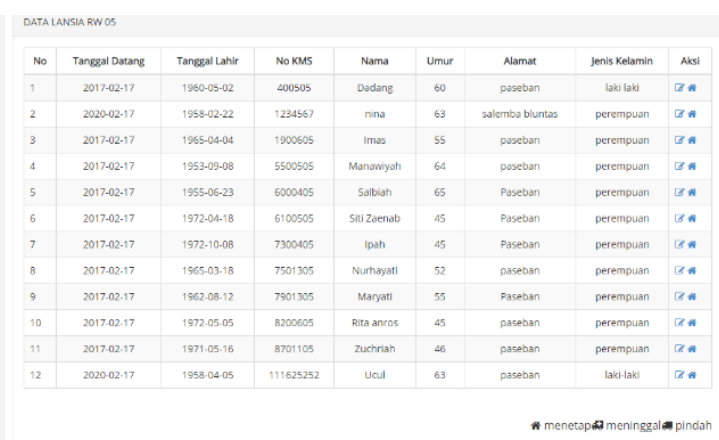

Gambar 17. Tampilan Data Posyandu Lansia

SELAMAT DATANG DI POSYANDU LANSIA RW 05

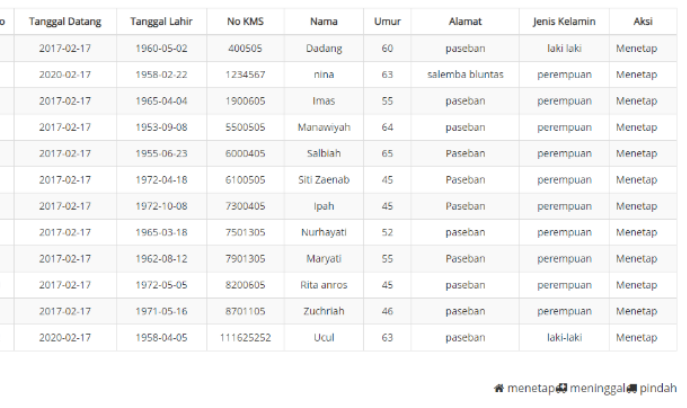

Gambar 18. Tampilan Data Posyandu Lansia Melalui Puskesmas

Pada gambar 17 tampilan data posyandu lansia terdapat beberapa nama lansia yang sudah datang ke pemeriksaan kesehatan posyandu lansia serta sudah di input dan ada kolom aksi yang dapat mengubah status tinggal lansia yaitu meninggal, menetap atau pindah. Pada gambar 18 tampilan data posyandu lansia melalui puskesmas terdapat beberapa nama lansia yang sudah datang ke pemeriksaan kesehatan posyandu lansia. Dikarenakan admin puskesmas hanya dapat melihat maka admin puskesmas tidak dapat menambah data dan mengubah data lansia. 


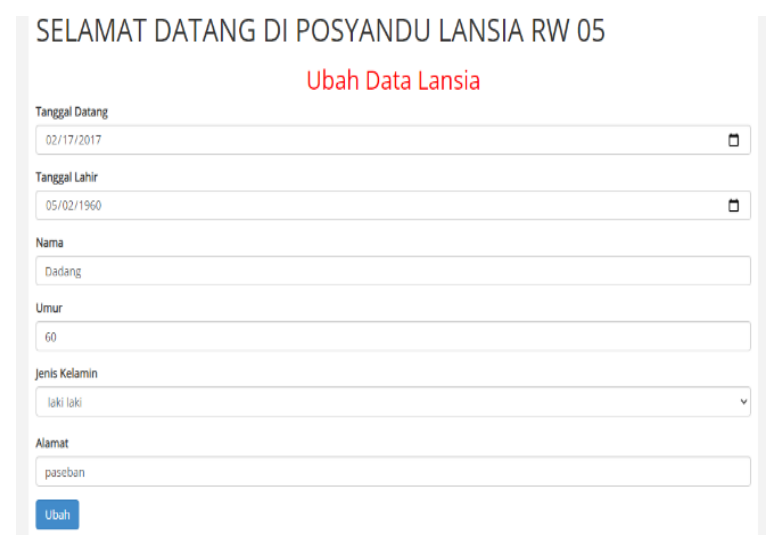

Gambar 19. Tampilan Ubah Data Posyandu Lansia

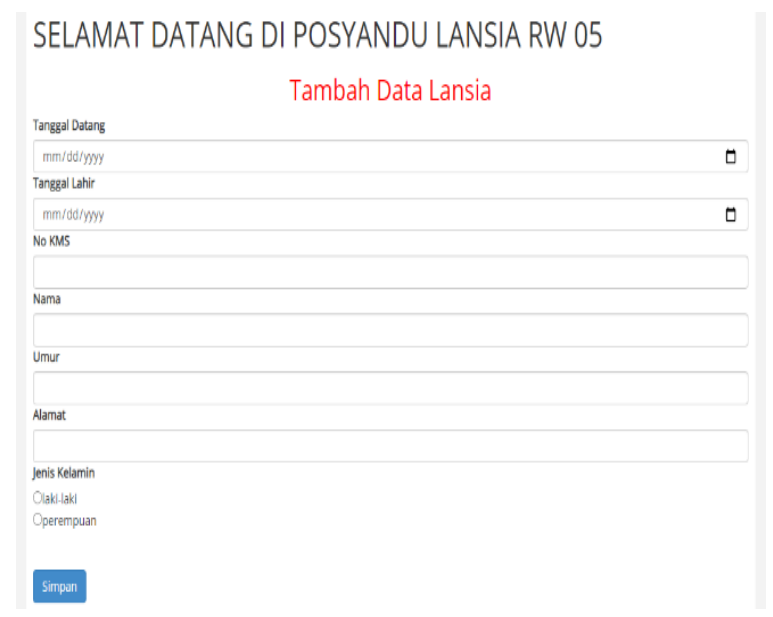

Gambar 20. Tampilan Tambah Data Posyandu Lansia

Pada gambar 19 tampilan ubah data posyandu lansia, kader posyandu lansia dapat mengubah tanggal datang, tanggal lahir, nama, umur, jenis kelamin dan alamat lansia apabila ada kesalahan dalam penginputan data.Pada gambar 20 tampilan tambah data posyandu lansia, kader posyandu lansia dapat menginputkan tanggal datang, tanggal lahir, nama, umur, jenis kelamin dan alamat lansiayang baru ikut serta dalam pelaksanaan pemeriksaan lansia.

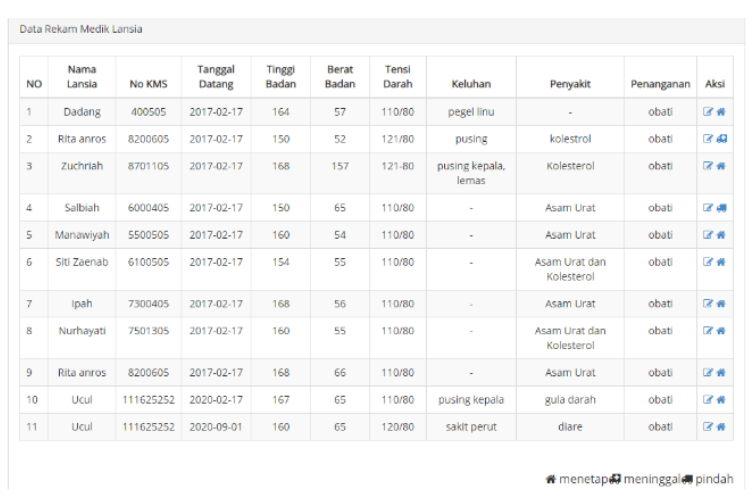

Gambar 21. Tampilan Data Rekam Medik Lansia

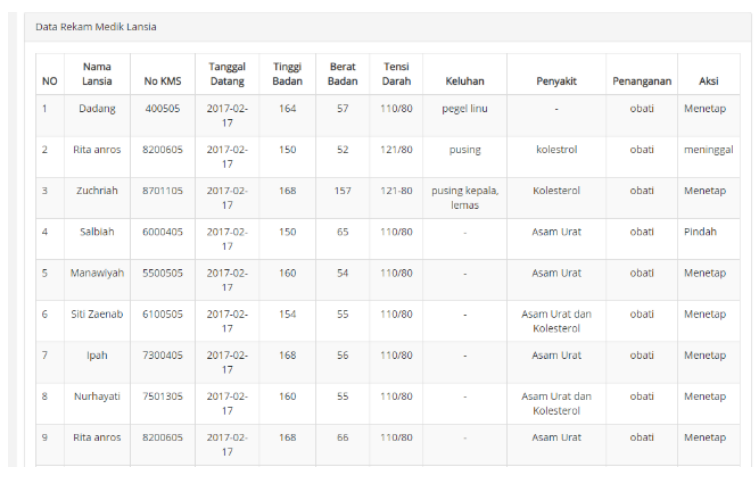

Gambar 22. Tampilan Data Rekam Medik Lansia Melalu Puskesmas

Pada gambar 21 tampilan data rekam medik lansia terdapat beberapa data lansia yang sudah datang ke pemeriksaan kesehatan posyandu lansia juga sudah diperiksa oleh para kader posyandu dan ada kolom aksi yang dapat mengubah status tinggal lansia yaitu meninggal, menetap atau pindah. Pada gambar 22 tampilan data rekam medik lansia melalui puskesmas terdapat beberapa nama lansia yang sudah datang ke pemeriksaan kesehatan posyandu lansia. Dikarenakan admin puskesmas hanya dapat melihat maka admin puskesmas tidak dapat menambah data dan mengubah data lansia. 


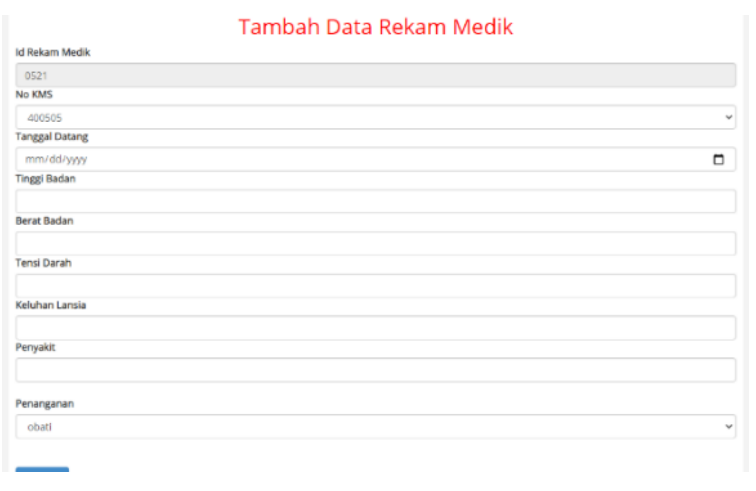

Gambar 23. Tampilan Tambah Data Rekam Medik Lansia

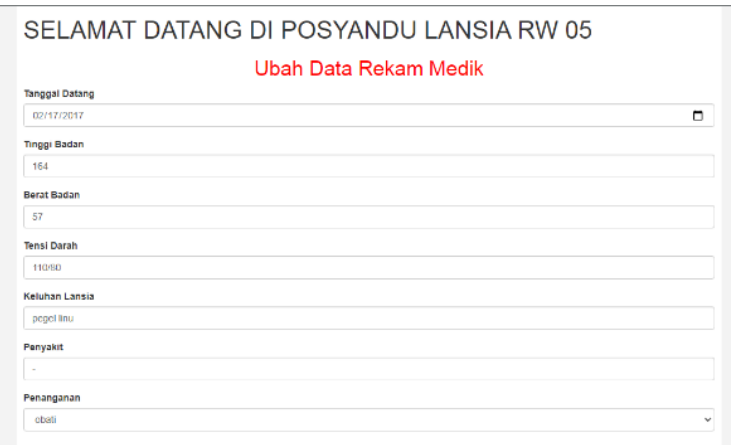

Gambar 24. Tampilan Ubah Data Rekam Medik

Pada gambar 23 tampilan tambah data rekam medik lansia untuk kolom id rekam medik dan no kms sudah otomatis terisi dan kader hanya perlu menginputkan tanggal datang, tinggi badan, berat badan, tensi darah, keluhan lansia, diagnosa penyakit dan penanganan perlu di obati atau di rujuk.Pada gambar24 tampilan ubah data rekam medik, kader posyandu lansia dapat mengubah tanggal datang, tinggi badan, berat badan, tensi darah, keluhan lansia, diagnosa penyakit dan penanganan di obati atau di rujuk apabila ada kesalahan dalam penginputan data.

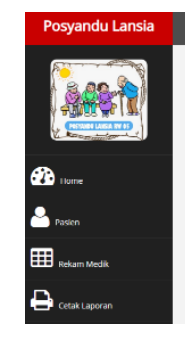

Gambar 25. Tampilan Cetak Laporan Melalui Admin Lansia dan Admin Puskesmas

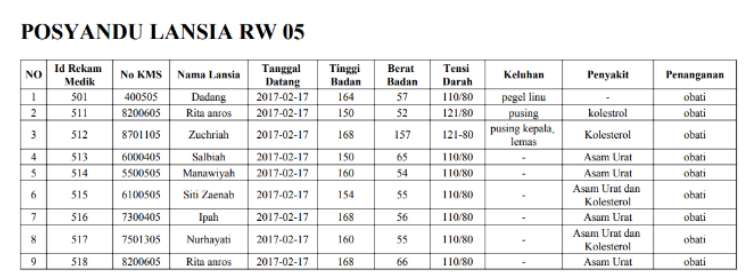

Gambar 26. Tampilan Hasil Cetak Data Lansia Melalui Admin Lansia dan Admin Puskesmas

Pada gambar 25 tampilan cetak laporan, kader posyandu lansia atau kader puskesmas dapat memilih tanggal mulai sampai tanggal akhir data lansia yang ingin di cetak.Pada gambar 26 tampilan hasil cetak data lansia adalah hasil data lansia mengenai rekam mediknya pada tanggal lansia tersebut datang, dapat di lihat tercantum lengkap dari mulai id rekam medik, no kms, nama lansia, tanggal datang, tinggi badan, berat badan, tensi darah, keluhan lansia, diagnosa penyakit dan penanganannya.

\section{Conclusions}

Pada penelitian ini dapat diambil kesimpulan bahwa berdasarkan hasil penyuluhan dan kuesioner, website ini dapat dikatakan berhasil karena kader posyandu dapat menggunakan website dengan baik. Kelemahan untuk penelitian ini yaitu 
pencatatan data laporan pemeriksaan lansia yang sebelumnya masih secara manual dan datanya yang terkadang tidak lengkap sehingga peneliti sulit menemukan bahan untuk diteliti. Saran yang diberikan adalah untuk selalu memberikan update atau pembaruan pada sistem pada program agar parakaderposyandu dapat menggunakan program dengan mudah dan dapat dimengerti. Dengan solusi yang peneliti berikan para kader lansia sudah dapat merasakan manfaat website tersebut yaitu data-data lansia yang mudah diperbarui, meminimalisir kesalahan pencatatan dan singkatnya waktu pelaksanaan posyandu, hal ini dapat dilihat selama kami melakukan penyuluhan dan uji coba web ini kepada mereka. Saat ini efektivitas dalam mengolah data riwayat pemeriksaan lansia sudah berjalan dengan lancar, tidak ada lagi keterlambatan dalam mengolah data-data lansia.

\section{References}

Haqi, B., \& Setiawan, H. S. (2019). Aplikasi

Absensi Dosen dengan Java dan Smartphone sebagai Barcode Reader. PT. Gramedia.

Hidayat, H., Hartono, \& Sukiman. (2017). Pengembangan Learning Management System (LMS) untuk Bahasa Pemrograman PHP. Jurnal Ilmiah Core IT: Community Research Information
Technology, 5(1), 20-29.

Hidayat, R. (n.d.). Cara Praktis Membangun Website Gratis. Elex Media Komputindo.

Intarti, W. D., \& Khoriah, S. N. (2018). Faktor-Faktor yang Mempengaruhi Pemanfaatan Posyandu Lansia. Journal of Health Studies, 2(1), 110-122. https://doi.org/10.31101/jhes.439

Keumalahayati, \& Alamsyah, T. (2018). Hubungan Pengetahuan dan Dukungan Keluarga terhadap Kegiatan Posyandu Lansia. Jkep, 3(1), 1-14. https://doi.org/10.32668/jkep.v3i1.196 Kristania, Y. M., \& Yulianti, F. D. (2019). Perancangan Sistem Informasi Pelayanan Pada Posyandu Pepaya Purwokerto. EVOLUSI - Jurnal Sains Dan Manajemen, 7(1), 68-75. https://doi.org/10.31294/evolusi.v7i1.5 015

Kusumawardani, D., \& Andanawarih, P. (2018). Peran Posyandu Lansia Terhadap Kesehatan Lansia Di Perumahan Bina Griya Indah Kota Pekalongan. Siklus : Journal Research Midwifery Politeknik Tegal, 7(1), 273277.

https://doi.org/10.30591/siklus.v7i1.74 8

Nuraeni, A., Rosiah, R., Nirwana, B., Putri, D. D., Rosita, I. N., Handayani, F., \& Afifah, A. (2020). Pengabdian 
Masyarakat: Pengecekan Kesehatan (Tekanan Darah, Kolesterol, Gula Darah Dan Asam Urat ) Di Desa Sukadana Compreng Kab. Subang. Jurnal Ilmiah Ilmu Dan Teknologi Rekayasa, 3(1), 66-72. https://doi.org/10.31962/jiitr.v3i1.67

Nurajijah, \& Indriani, K. (2017). Implementasi Model Waterfall Pada Pembangunan Sistem Informasi Akademik Berbasis Web Pada Smk Yapipa Serpong Utara. TECHNO Nusa Mandiri, $\quad$ 14(2), 77-82. http://ejournal.nusamandiri.ac.id/ejurna 1/index.php/techno/article/view/480

Ramadhan, A. M., Parihah, A., Andriyani, A., Assidqy, B., Nurfatimah, D., Trianita, R., AL-Rosyid, F., Faoziah, I., Afifah, I., Ramdahan, R. A., Risnandar, R., \& Reni. (2019). Profil dan Potensi Desa Cukang Kawung (Kec. Sodong Hilir, Kab. Tasikmalaya) (E. F. F. Khomaeny (ed.)). Edu Publisher.

Risanty, R. D., \& Sopiyan, A. (2017). Pembuatan Aplikasi Kuesioner Evaluasi Belajar Mengajar Menggunakan Bot Telegram Pada Fakultas Teknik Universitas Muhammadiyah Jakarta (Ft-Umj) Dengan Metode Polling. Seminar Nasional Sains Dan Teknologi, 2(November), 1-9.

Rohman, H., \& Agnia, E. (2019). Pelaporan
Posyandu Lansia Puskesmas Banguntapan III : Perancangan Sistem Informasi Berbasis Web. Indonesian of Health Information Management Journal, 7(2), 44-53.

Rohman, H., \& Aminaa, T. N. (2018). Perancangan Sistem Informasi Pelaporan Posyandu Lansia. Jurnal Manajemen Informasi Dan Administrasi Kesehatan (J-MIAK), 01(02), 1-6.

Sundari, J. (2016). Sistem Informasi Pelayanan Puskesmas Berbasis Web. IJSE - Indonesian Journal on Software Engineering, 2(1), 44-49.

Syukron, A., \& Hasan, N. (2015). Perancangan Sistem Rawat Jalan Berasis web Pada Puskesmas Winog. Informatika, 3(1), 28-34.

Tanjung, I. (2017). Perancangan Sistem Informasi Rekam Medis Terpadu Dalam Upaya. Jurnal Intra-Tech, 1(1), 43-54.

Waluyo, A., \& Fatich, E. V. L. N. (2017). Perancangan Website Dinas Pendidikan Pemuda Dan Olah Raga (Studi Kasus Dinas Pendidikan Pemuda Dan Olah Raga Kabupaten Kebumen). J-SAKTI (Jurnal Sains Komputer Dan Informatika), $\quad 1(2), \quad 186$. https://doi.org/10.30645/j-sakti.v1i2.42 Wulansari, T. (2015). Studi Deskriptif Implementasi Program Posyandu 
Lanjut Usia di RW IV Kelurahan

Tanah Kali Kedinding Kecamatan

Kenjeran Surabaya. Kebijakan Dan

Manajemen Publik, 3(April), 1-9.

https://doi.org/10.1007/s10840-006-

9010-z

Yulianita, S., Rosely, E., \& Hernawati, E. (2015). Aplikasi Berbasis Web Untuk Pengelolaan Data Pasien Rawat Jalan

Di Puskesmas Cikijing. E-Proceeding of Applied Science, 1(3), 1646. https://doi.org/10.1017/CBO97811074 15324.004 